\title{
AN EXAMINATION OF CHILD NEGLECT IN TERMS OF SOCIO-DEMOGRAPHIC VARIABLES
}

\author{
Utku Beyazit $^{1}$, Aynur Bütün Ayhan ${ }^{2}$ \\ ${ }^{1}$ Assist. Prof. Dr, Akdeniz University, Kumluca Health Sciences Faculty, Child Development \\ Department, Antalya, Turkey \\ ${ }^{2}$ Prof. Dr., Ankara University, Health Sciences Faculty, Child Development Department, Ankara, \\ Turkey
}

\begin{abstract}
Child neglect is the situation where adults are incapable of meeting the needs, maintaining the wellbeing and providing protection for the children under their care. In order to prevent child neglect, it is crucial to identify the families in the risk group. In this regard, identifying the socio-demographic factors relevant to child neglect would help in identifying the children under the risk. Thus, this study aimed to examine child neglect in terms of sociodemographic variables. The participants of the study consisted of 402 secondary school students in Ankara, Turkey. The students were administered "Socio-Demographic Information Form" in order to gather socio-demographic information. The students were also administered "Multidimensional Neglectful Behavior Scale (10-15 Years Form)" in order to assess their neglect experiences by their parents. As a result, it was found that children's neglect experiences by their mothers and fathers differed according to children's age, grade level, school success, whether they spend time on social media, the level of their relationships with their parents and whether they actively spend time with their mothers and fathers. It was also found that children's neglect experiences differed according to the age and education level of their fathers. As a result of the research, certain proposals as with the prevention of child neglect were brought for the prevention of child neglect.
\end{abstract}

Keywords: child, child neglect, socio-demographic variables 


\section{1-23 December, 2018 in Berlin - Germany}

\section{Introduction}

Child neglect is described as the situation where adults are incapable of meeting the needs, maintaining the wellbeing and providing protection for the children under their care and thus, the child's development being affected negatively (Scannapieco and Connell-Carrick, 2005; Palusci, 2011). While child neglect is generally examined under various headings as physical neglect, medical neglect, emotional neglect, supervisory neglect, cognitive neglect and educational neglect (Straus, 2004; McCoy and Keen, 2014), it is difficult to distinguish the neglect types from each other as it occurs chronically and multiple types occurring simultaneously (Howe, 2005; Laskey, 2011).

Every year, millions child neglect cases are reported but approximately one third of these cases are being recorded as identified (Baysal and Şahin, 2014). In their report in 2003, UNICEF suggested that child maltreatment is an issue in both developed and developing countries. According to the report, 3500 children every year lose their lives due to maltreatment in industrialized countries (UNICEF, 2003). In a meta-analysis study where data from seven hundred and ninety-five studies were examined, it was found that for physical neglect the prevalence rate is $19.2 \%$ in North America continent and 6.5\% in Europe whereas, for emotional neglect the rate is $14.5 \%$ in North American and 30.1\% in Asia (Stoltenborgh et al., 2013). Not many studies exist about the prevalence and status of child neglect in Turkey; and although physical neglect is seen more, it is ignored unless the case results in death or severe injuries (Pakiş et al, 2008).

Neglect can result in both physical and developmental consequences. Physical findings may result in growth failure without an organic reason (Smitherman, 2011; Block and Krebs, 2015) and developmental problems such as decrease in cognitive abilities and academic failure during school period (Stone, 2007; Nadeau and Nolin, 2013), bedwetting and learning difficulties (Lewin and Herron, 2007; Chen et al., 2011), communication problems (De Paul and Guibert, 2008); behavioral problems such as aggression and lying (Fang and Corso, 2007; Kotch et al., 2008); depression, anxiety and conduct disorder (Nikulina, 2011; Norman et al., 2012). Severe cases of neglect may result in death (Schmidt, 2011). 


\section{1-23 December, 2018 in Berlin-Germany}

Child neglect occurs more frequently if certain risk factors exist in the family and the child (Hindley et al, 2006). Child requiring special care due to premature birth (Dunn et al., 2002; Bugental and Happaney, 2004); being born as a result of unplanned pregnancy, being disabled (Doğru, 2006; Kantarcı et al., 2013); are factors that increase the risk for child neglect. Child's age and gender are also among the risk factors regarding children (Chen et al., 2011; PerezFuentes et al., 2013; Douglas, 2014); that is, younger children are exposed to neglect more compared to older children. Types of neglect, on the other hand, differentiate based on gender; girls are exposed to educational neglect whereas, boys are exposed to physical or supervisory neglect (Beyazova, 2014, Clement et al., 2016). Various studies on risk factors relevant to parents showed that low education (Güler et al., 2002; Dallar Bilge et al., 2013) and low socioeconomic level (Schumacher et al., 2001; Berger, 2004; Duva and Metzger, 2010; Lee et al., 2012); violence and communication problems between spouses (Waldfogel et al, 2010; Nicklas, 2012); having children at an early age (Köse et al., 2013), number of children in the household (Altıparmak et al., 2013); social isolation and lack of social support (Berry et al., 2003; Lewin and Herron, 2007) and various mental problems of the parents (Stith et al., 2009) are among the most prominent risk factors.

In order to prevent child neglect, it is crucial to identify the families in the risk group. In this regard, it is believed that identifying the socio-demographic factors relevant to child neglect would help in identifying the children under the risk. Thus, this study aimed to examine child neglect in terms of socio-demographic variables.

\section{Methodology}

\subsection{Participants}

The study group consisted of 402 children who were studying in two different secondary schools in the city center of Ankara, during the 2017-2018 Spring Semester. The average age of the children is $12.31 \pm 1.38$ with $49.8 \%(n=200)$ of them being female and $50.2 \%(n=202)$ being male. Among the children, $26.1 \%(\mathrm{n}=105)$ were from $5^{\text {th }}$ grade, $24.4 \%(\mathrm{n}=98)$ from $6^{\text {th }}$ grade, $21.6 \%(\mathrm{n}=87)$ from $7^{\text {th }}$ grade and $27.9 \%(\mathrm{n}=112)$ from $8^{\text {th }}$ grade. 
International Conference on

\section{SOCIAL SCIENCE, HUMANITIES \& EDUCATION}

21-23 December, 2018 in Berlin - Germany

\subsection{Instruments}

In the study Socio-Demographic Information Form was administered in order to gather data regarding the socio-demographic background of the children. In addition, Multidimensional Neglectful Behavior Scale 10-15 Years Old Child Form was administered in order to examine the neglect experiences of the children.

Socio-Demographic Information Form: The form, which was prepared by the researchers, included questions about the gender, age, grade, academic achievements, number of siblings, relationships with their parents, social networking, parents' age and level of education.

Multidimensional Neglectful Behavior Scale (MNBS) 10-15 Years Old Child form: Multidimensional Neglectful Behavior Scale 10-15 Years Old Child Form was developed by Kaufman Kantor et al. in 2004 in the United States of America with the aim of assessing the neglect experiences of children by their parents. The original scale includes two different forms as Mother Form and Father Form each of which consists of 65 cards. Each from includes 9 subdimensions: emotional, cognitive, supervisory and physical neglect, abandonment, insufficient protection and use of alcohol, depression and social desirability. In the reliability analysis of the scale, the Cronbach Alpha coefficient for internal consistency was found as .95 (Kaufman Kantor et al., 2004).

The Turkish adaptation of the scale was conducted by Beyazit and Bütün Ayhan (2018). The Turkish Mother Form of the scale includes 51 items and 8 sub-dimensions, namely, cognitive, emotional, physical and supervisory neglect; insufficient protection, general neglect, depression and social acceptance. The Father Form includes 57 items and 9 sub-dimensions: cognitive, emotional, physical, supervisory and general neglect; abandonment, failure to protect, depression and social acceptance. During implementation, children are individually shown cards with pictures and asked which children in the pictures look most like themselves. Each card shows drawings regarding the evaluation of children's neglect experiences. Children's responses are recorded in two separate forms, one for mother and one for father, and each response showing their neglect experiences are given one point. The scores for depression and social acceptance are not included in the total neglect scores. For the Father Form, the minimum score is 0 and the maximum score is 41 . For the Mother Form, the minimum neglect score is 0 and the maximum neglect score is 35 . 
International Conference on

\section{SOCIAL SCIENCE, HUMANITIES \& EDUCATION}

\section{1-23 December, 2018 in Berlin - Germany}

The high scores received from the scale indicate high levels of neglect experienced by the child. The reliability analysis results of the Turkish form showed that the Cronbach Alpha coefficient for the Mother Form is 0.832 and for the Father Form, it is 0.908 (Beyazit and Bütün Ayhan, 2008). The internal consistency analysis conducted for this study showed that the Cronbach Alpha value for the Mother Form is 0.69 and for the Father Form, it is 0.81 .

\subsection{Data Collection and Data Analysis}

Required permissions for the administrations of the instruments were provided from the Ministry of National Education. For the implementation of the instruments, school directors and teachers were contacted to determine the suitable days and time. During implementation, children were informed about the aim of the study and their oral consent was taken regarding their participation in the study. The instruments were implemented to only those children who accepted to participate in the study. Prior to the onset of the analysis, normality test was conducted in order to determine whether the data collected meet the parametric test conditions or not. The results of the Kolmogorof-Smirnov test, showed that the scores of the Multidimensional Neglectful Behavior Scale do not show a normal distribution ( $p>.05$ ). Hence, Mann Whitney $U$ test was performed to compare variables with two groups, and Kruskal Wallis-H test to compare variables with three or more groups (Büyüköztürk, 2004).

\section{Results}

An examination of the Multidimensional Neglectful Behavior Scale-Mother Form revealed that scores varied between 0 and 23 with a mean score of 5.12 \pm 4.23 . On the other hand Father Form scores varied between 0 and 38 with a mean of $8.66 \pm 6.64$. Table 1 shows the comparison of Multidimensional Neglectful Behavior Scale-Mother Form scores according to the children's socio-demographic characteristics. 


\section{International Conference on SOCIAL SCIENCE, HUMANITIES \& EDUCATION}

\section{$21-23$ December, 2018 in Berlin - Germany}

Table 1. The Comparison of Multidimensional Neglectful Behavior Scale-Mother Form Scores according to the Children's Socio-Demographic Characteristics

\begin{tabular}{|c|c|c|c|c|c|}
\hline Socio-Demographic Characteristics & $\mathbf{n}$ & Mean Rank & $\mathbf{x}^{2} / Z^{a}$ & $\mathbf{p}$ & Difference \\
\hline \multicolumn{6}{|l|}{ Socioeconomic Status } \\
\hline Low & 149 & 193.74 & 1.640 & 0.440 & \\
\hline Average & 114 & 200.00 & & & \\
\hline High & 139 & 211.05 & & & \\
\hline \multicolumn{6}{|l|}{ Age } \\
\hline 10 years old & 43 & 151.30 & 49.294 & $0.000 *$ & $1,2-4$ \\
\hline 11 years old & 91 & 156.79 & & & $1,2,3,4-5$ \\
\hline 12 years old & 77 & 187.50 & & & \\
\hline 13 years old & 86 & 218.04 & & & \\
\hline 14 years old and above & 105 & 257.52 & & & \\
\hline \multicolumn{6}{|l|}{ Gender } \\
\hline Female & 200 & 195.17 & -1.093 & 0.275 & \\
\hline Male & 202 & 207.77 & & & \\
\hline \multicolumn{6}{|l|}{ Grade } \\
\hline $5^{\text {th }}$ grade & 105 & 154.80 & 45.454 & $0.000 * *$ & $1-2,3$ \\
\hline $6^{\text {th }}$ grade & 98 & 190.07 & & & $1,2,3-4$ \\
\hline $7^{\text {th }}$ grade & 87 & 197.36 & & & \\
\hline $8^{\text {th }}$ grade & 112 & 258.50 & & & \\
\hline \multicolumn{6}{|l|}{ Number of Siblings } \\
\hline No siblings & 65 & 172.40 & 5.544 & 0.136 & \\
\hline 1 sibling & 212 & 197.75 & & & \\
\hline 2 siblings & 70 & 188.69 & & & \\
\hline 3 and more siblings & 29 & 156.48 & & & \\
\hline \multicolumn{6}{|l|}{ Mother's age } \\
\hline 40 years old and younger & 272 & 198.89 & 0.925 & 0.630 & \\
\hline $41-50$ years old & 124 & 207.09 & & & \\
\hline 51 years old and above & 5 & 165.00 & & & \\
\hline \multicolumn{6}{|l|}{ Mother's education } \\
\hline Graduate of primary school & 72 & 211.69 & 0.949 & 0.814 & \\
\hline Graduate of secondary school & 69 & 201.01 & & & \\
\hline Graduate of high school & 138 & 202.17 & & & \\
\hline Graduate of university & 123 & 195.05 & & & \\
\hline \multicolumn{6}{|l|}{ Level of relationship with mother } \\
\hline Well & 349 & 190.17 & 24.268 & $0.000 * *$ & \\
\hline
\end{tabular}


International Conference on SOCIAL SCIENCE, HUMANITIES \& EDUGATION

21-23 December, 2018 in Berlin - Germany

\begin{tabular}{llllll} 
Moderate & 47 & 269.83 & & & \\
Poor & 5 & 309.60 & & & \\
School Success & & & & & \\
Successful & 212 & 170.36 & 37.547 & $0.000^{* * *}$ & $1-2$ \\
Moderately successful & 163 & 228.64 & & & $1,2-3$ \\
Unsuccessful & 27 & 282.20 & & & \\
Social networking & & & & & \\
Yes & 308 & 207.97 & -2.376 & $0.018^{*}$ & \\
No & 92 & 175.51 & & & \\
Time spent on social media per day & & & & & \\
Less than half an hour & 89 & 143.93 & 7.239 & 0.065 & \\
30 minutes-1 hour & 88 & 164.36 & & & \\
2-3 hours & 86 & 175.71 & & & \\
More than 3 hours & 66 & 180.31 & & & \\
Spending time with mother & & & & & \\
Yes & 293 & 177.15 & -6.925 & $0.000^{* * *}$ & \\
No & 109 & 266.95 & & & \\
\hline
\end{tabular}

Table 1 shows the findings of the analysis performed to compare the scores of Multidimensional Neglectful Behavior Scale-Mother Form according to the children's sociodemographic characteristics. The results of the Mann Whitney-U test revealed that the neglect scores did not differ according to the gender of the children $(z=-1.093 ; p>.05)$. However, children's neglect scores were higher in terms of social networking $(z=-2.376, p<.05)$ and spending time with mothers $(z=-6.925, p<.01)$; that is, the children who are involved in social networking through their cell phones or computers and the children who do not spend time with their mothers had significantly higher mean ranks. 


\section{1-23 December, 2018 in Berlin-Germany}

The results of the Kruskal Wallis test revealed that the neglect scores did not differ according to socio-economic status $\left(x^{2}=1.640 ; p>.05\right)$, number of siblings $\left(x^{2}=5.544 ; p>.05\right)$, mother' age $\left(x^{2}=0.925 ; p>.05\right)$, mother's education $\left(x^{2}=0.949 ; p>.05\right)$ and the daily duration of social networking $\left(x^{2}=7.239 ; p>.05\right)$. On the other hand, children's neglect scores were higher in terms of children's age $\left(x^{2}=49.294 ; p<.01\right)$, grade $\left(x^{2}=45.454 ; p<.01\right)$, level of relationship with mother $\left(x^{2}=24.268 ; p<.01\right)$ and school success $\left(x^{2}=37.547 ; p<.01\right)$. A further examination by using Mann Whitney-U test revealed that the children who were 13 years old and 14 years old and above; who were attending to $7^{\text {th }}$ and $8^{\text {th }}$ grade; whose relationship with mother were poor and who are moderately successful and unsuccessful at school had significantly higher mean ranks.

Table 2 shows the comparison of Multidimensional Neglectful Behavior Scale-Father Form scores according to the children's socio-demographic characteristics.

\begin{tabular}{|c|c|c|c|c|c|}
\hline & $\mathbf{n}$ & Mean Rank & $\mathbf{x}^{2} / \mathbf{Z}^{\mathrm{a}}$ & $\mathbf{p}$ & Difference \\
\hline \multicolumn{6}{|l|}{ Socioeconomic Status } \\
\hline Low & 149 & 214.69 & 3.082 & 0.214 & \\
\hline Average & 114 & 194.84 & & & \\
\hline High & 139 & 192.82 & & & \\
\hline \multicolumn{6}{|l|}{ Age } \\
\hline 10 years old & 43 & 134.03 & 60.839 & $0.000^{* *}$ & $1-3,4,5$ \\
\hline 11 years old & 91 & 149.73 & & & $2-3,4,5$ \\
\hline 12 years old & 77 & 202.01 & & & $3,4-5$ \\
\hline 13 years old & 86 & 218.77 & & & \\
\hline 14 years old and above & 105 & 259.48 & & & \\
\hline \multicolumn{6}{|l|}{ Gender } \\
\hline Female & 200 & 195.39 & -1.052 & 0.293 & \\
\hline Male & 202 & 207.55 & & & \\
\hline \multicolumn{6}{|l|}{ Grade } \\
\hline $5^{\text {th }}$ grade & 105 & 136.11 & 59.365 & $0.000^{* *}$ & $1-2,3,4$ \\
\hline $6^{\text {th }}$ grade & 98 & 195.86 & & & $2,3-4$ \\
\hline $7^{\text {th }}$ grade & 87 & 217.54 & & & \\
\hline $8^{\text {th }}$ grade & 112 & 255.28 & & & \\
\hline \multicolumn{6}{|l|}{ Number of Siblings } \\
\hline No siblings & 65 & 170.09 & 2.453 & 0.484 & \\
\hline 1 sibling & 212 & 193.62 & & & \\
\hline 2 siblings & 70 & 191.81 & & & \\
\hline
\end{tabular}




\section{International Conference on SOCIAL SCIENCE, HUMANITIES \& EDUCATION}

21-23 December, 2018 in Berlin - Germany

3 and more siblings

\section{Father's age}

40 years old and younger

41-50 years old

51 years old and above

\section{Father's education}

Graduate of primary school

Graduate of secondary school

Graduate of high school

Graduate of university

Level of relationship with father

Well

Moderate

Poor

\section{School Success}

Successful

Moderately successful

Unsuccessful

\section{Social networking}

Yes

No

Time spent on social media per day

Less than half an hour

30 minutes-1 hour

2-3 hours

More than 3 hours

Spending time with father

Yes

No
29

213.68

210.99

$47 \quad 238.34$

$62 \quad 226.65$

$132 \quad 204.90$

$161 \quad 178.27$

$340 \quad 187.68$

$55 \quad 275.50$

7

291.57

171.40

228.92

27

272.30

$308 \quad 208.07$

$92 \quad 175.15$

$89 \quad 134.70$

$88 \quad 164.06$

$86 \quad 181.59$

$66 \quad 185.51$
$6.791 \quad 0.034 * \quad 1-2$

$14.231 \quad 0.003 * \quad 4-1,2$

$31.447 \quad 0.000 * * \quad 1-2,3$

$33.454 \quad 0.000 * * \quad 1-2,3$

$-2.4020 .016^{*}$

$14.7750 .002 * \quad 1-2,3,4$

$276 \quad 172.90$

$-7.3190 .000 * *$

Table 2. The Comparison of Multidimensional Neglectful Behavior Scale-Father Form Scores According To The Children' Socio-Demographic Characteristics

${ }^{a} Z$ değeri Mann-Whitney $U, x^{2}$ değeri ise Kruskal-Wallis testine ilişkin sonuçları belirtmektedir. ${ }^{*} p<0.05,{ }^{* *} p<0.01$ 


\section{1-23 December, 2018 in Berlin - Germany}

Table 2 shows the findings of the analysis performed to compare the scores of Multidimensional Neglectful Behavior Scale-Father Form according to the children's sociodemographic characteristics. The results of the Mann Whitney-U test revealed that the neglect scores did not differ according to the gender of the children $(z=-1.052 ; p>.05)$ whereas children's neglect scores differed according to social networking $(z=--2.402, p<.05)$ and spending time with fathers $(z=-7.319, p<.01)$. That is, the children who are involved in social networking through their cell phones or computers and the children who do not spend time with their fathers had significantly higher mean ranks.

An examination of the Kruskal Wallis test results revealed that the neglect scores did not differ according to socio-economic status $\left(x^{2}=3.082 ; p>.05\right)$ and number of siblings $\left(x^{2}\right.$ $=2.453 ; p>.05)$. However, children's neglect scores were higher in terms of children's age $\left(x^{2}\right.$ $=60.839 ; p<.01)$, grade $\left(x^{2}=59.365 ; p<.01\right)$, father's age $\left(x^{2}=6.791 ; p<.05\right)$, father's education level $\left(x^{2}=14.231 ; p<.05\right)$, level of relationship with father $\left(x^{2}=31.447 ; p<.01\right)$, school success $\left(x^{2}=33.454 ; p<.01\right)$ and time spent on social media per day $\left(x^{2}=14.775 ; p<.01\right)$. A further examination by using Mann Whitney-U test revealed that the children who were 13 years old and 14 years old and above; who were attending to $7^{\text {th }}$ and $8^{\text {th }}$ grade; whose fathers were 41-50 years old, graduate of primary and secondary school; whose relationship with father were poor and who are moderately successful and unsuccessful at school had significantly higher mean ranks.

\section{Discussion}

This study aimed to examine child neglect in terms of socio-demographic variables. The results of the study showed that child's age, grade, academic success, status of social media usage, level of relationship with parents and active time spent with parents are mutual variables for both mothers and fathers regarding neglect. The findings also indicated that, unlike mothers, fathers' level of neglect shows differences according to their age and level of education. In terms of the age of the child, the findings of this study are inconsistent with a number of studies in the literature. 


\section{1-23 December, 2018 in Berlin-Germany}

Various studies have shown that level of child neglect varies according to age; that is, younger children are neglected more (Chen et al., 2011; Perez-Fuentes et al., 2013; Soylu et al., 2013; Douglas, 2014). However in the present study, it was found that older children experienced higher levels of neglect. Although, children of all age groups are exposed to neglect, older children may be at risk particularly in terms of physical and supervisory neglect (Human Rights Association, 2008; Polat, 20017). A similar result was found in terms of the grade that the children attended. It is thought that the data gathered from the study regarding grade can be associated with age variable; that is, children at older grades are neglected more by their parents.

It was found that children who are neglected by their parents also have a low success rate in school. A number of studies in the literature also indicate the relationship between neglect and low school success (Stone, 2007; McBride et al., 2005; Nikulina et al., 2011). Parents are important stimuli for the cognitive development of their children. In addition to the many factors affecting brain development and academic success, it is also highlighted that the attention parents pay to the children and their attitude towards education have positive impact on the children's brain, academic success, analytical thinking skills, verbal skills, and language development (Pancsofar and Vernon-Feagans 2002). It is believed that, recently, many parents spend limited time with their children, the communication between parents and children are limited to daily, and although chronic neglect is not in question, parents are not able to pay sufficient attention to their child's education.

Other significant findings of the study showed that children who define their relation with parent as poor and those who do not spend active time with their parents have higher rates of neglect. Attitudes and behaviors such as not providing sufficient stimuli to children since infancy, not paying attention to the care, ignoring the child, not showing love and respect, not listening carefully to what the child is saying, not keeping the promises given to the child, ignoring the child's success, not providing the child with the love and affection he needs are defined as emotional neglect (Lewin and Herron, 2007; Beyazova, 2014). 
International Conference on

\section{SOCIAL SCIENCE, HUMANITIES \& EDUCATION}

\section{1-23 December, 2018 in Berlin - Germany}

The more time parents spend with their children, the higher the quality of their relation (Lewis et al., 2008), parents' active sharing of the child's life has a positive impact on all developmental aspects of the child. In families where parents' involvement is insufficient and parent-child interaction is negative, parents do not show warmth and love; children do not feel safe and they are emotionally bruised (Polat, 2017).

In the present study, it was also found that children who use social media more have a higher rate of neglect. It is thought that children who do not receive sufficient attention from their parents tend to use social networks as a socializing tool and look for the attention they need in such contexts. Various studies also support this suggestion by showing that establishing social relations, looking for support and closeness are among the top reasons for the use of Internet among teenagers (Özcan and Buzlu, 2005, Kraut et al., 2002, Valkenburg and Peter, 2008). On the other hand, it is also believed that parents, who neglect their children, do not offer supervision to raise their children in a safe setting, do not set rules; do not guide children regarding right behavior and responsibilities to be fulfilled and do not protect children against the potential dangers of social networking; thus, children access the Internet in an unlimited manner and without supervision.

In the study, unlike the mothers, fathers' neglectful behaviors towards children showed differences depending on their age and level of education. In Turkish culture, traditionally mothers are seen as the primary caregiver of the child (Özen, 2009). However, equally important as the mothers' role, fathers also play a crucial role in a child's healthy development. It is stressed out that the involvement of fathers in a child's development, care and education is important for the cognitive, physical, social and emotional development of the child (Özkardeş, 2011). It was found in the study that fathers' at the age of forty or below have a lower rate of child neglect compared to other fathers. In contrast to this finding, the available literature suggests that older fathers are more attentive towards their children; and that age factor can be associated with emotional maturity and being aware of responsibilities (Castillo ve ark., 2011). It is believed that this finding may be resulting from the fact that equal gender roles are in the process of being established in Turkish society and the majority of young fathers are more involved in a child's care and education. 


\section{International Conference on SOCIAL SCIENCE, HUMANITIES \& EDUCATION}

\section{1-23 December, 2018 in Berlin - Germany}

The results of the study also showed that fathers who graduated from university have a lower rate of child neglect compared to other fathers. It is underlined that higher education level has a positive influence on the participation of father in the child's care (Shannon et al., 2005). Low education level, unemployment and low income level are among social stressors for neglect (Bahar et al., 2009). In this regard, low education level is believed to be leading to not only lack of knowledge and awareness regarding child neglect but also financial stressors. There are many studies available in the literature which emphasize that low education level is one of the risk factors regarding child maltreatment (Güler et al., 2002; Örsel et al. 2011).

This study is significant in terms of identifying certain socio-demographic factors which can be associated with child neglect. Identification of these factors is important for the efforts regarding the prevention of child neglect. Educational programs regarding child neglect should be designed for parents for the purpose of increasing the level of knowledge and awareness about the issue. It is crucial for the child's development for the parents to show the care and love needed by the child as all children need to feel that they are loved by their parents. It is equally important for the parent to not only meet the physical, medical and educational needs of children but also meet their emotional needs such as loving, acceptance and sense of belonging in addition to asking their thoughts and feelings, making the house a communicationfriendly setting and establishing opportunities to spend quality time together. In addition, parents should monitor what children do outside of home and who they spend time with; and house setting should not be left unattended and without any rules. Habits such as watching TV and use of Internet should also be supervised and access to Internet should be monitored.

\section{References}

[1] Altıparmak, S., Yıldırım, G., Yardımc1, F., \& Ergin, D. (2013). Annelerden alınan bilgilerle çocuk istismarı ve etkileyen etkenler. Anadolu Psikiyatri Dergisi, vol. 14, pp. 354-361.

[2] Bahar, G., Savaş, H. A., \& Bahar, A. (2009). Çocuk istismarı ve ihmali: Bir gözden geçirme. Fırat Sağllk Hizmetleri Dergisi, vol. 4(12), 51-65.

[3] Baysal, S. U., \& Şahin, F. (2014). Çocuk istismarı ve ihmali. Türkiye Milli Pediatri Derneği ve Sosyal Pediatri Derneği Ortak Kılavuzu içinde (pp. 93-16). Ankara: Türkiye Milli Pediatri Derneği. 
[4] Berger, L. M. (2004). Income, family structure, and child maltreatment risk. Children and Youth Services Review, 26(8), pp. 725-748.

[5] Berry, M., Charlson, R., \& Dawson, K. (2003). Promising practices in understanding and treating child neglect. Child and Family Social Work, vol. 8, pp. 13-24.

[6] Beyazıt U. \& Bütün Ayhan A. (2018). The psychometric properties of the Turkish version of the Multidimensional Neglectful Behavior Scale-Parents Form. Current Psychology, (Online published article). Doi: https:// doi.org /10.1007/s12144-0189817-7.

[7] Beyazova, U. (2014). İhmal.Çocuk İstismarına ve İhmaline Yaklaşım. Temel Bilgiler. Ed.: O. Derman, Ankara: Akademisyen Tip Kitabevi, pp. 35-36.

[8] Block, R. W. \& Krebs, N. F. (2005). Failure to thrive as a manifestation of child neglect. American Academy of Pediatrics, vol. 116(5), pp. 1234-1237.

[9] Bugental, D. B., \& Happaney, K. (2004). Predicting infant maltreatment in low-income families: the interactive effects of maternal attributions and child status at birth. Developmental Psychology, 40(2), 234-243.

[10] Büyüköztürk Ş. (2004). Sosyal Bilimler İçin Veri Analizi El Kitabı, 4th Edition. Ankara: Pegem Akademi.

[11] Castillo, J.,Welch, G., \& Sarvermatern, C. (2011). Fathering: The relationship between fathers' residence, fathers' sociodemographic characteristics, and father involvement. Child Health J. Vol. 15, pp. 1342-1349.

[12] Chen, W., Propp, J., Delara, E., \& Corvo, K. (2011). Child neglect and its association with subsequent juvenile drug and alcohol offense. Child Adolesc Soc Work J, vol. 28, pp. 273-290.

[13] Clement, M. E., Berube, A., \& Chamberland, C. (2016). Prevalence and risk factors of child neglect in the general population. Public Health, pp. 1-7.

[14] Dallar Bilge, Y., Taşar, M.A., Kılınçoğlu, B., Özmen, S., \& Tıraş, Ü. (2013). Alt sosyoekonomik düzeye sahip anne-babaların çocuk istismarı ve ihmali hakkındaki bilgi düzeyleri, deneyimleri ve kullandıkları disiplin yöntemleri. Anadolu Psikiyatri Dergisi, vol. 14, pp. 27-35. 
21-23 December, 2018 in Berlin - Germany

[15] Depaul, J., \& Guibert, M. (2008). Empathy and child neglect: A theoretical model. Child Abuse \& Neglect, vol. 32, pp. 1063-1071.

[16] Doğru, Y. S. (2006). Zihin engelli çocuklarda cinsel istismar. Abant İzzet Baysal Üniversitesi Ĕ̈itim Fakültesi Dergisi, pp. 80-91.

[17] Douglas, E. M. (2014). A comparison of child fatalities by physical abuse versus neglect: child, family, service, and worker characteristics. Journal of Social Service Research, vol. 40, pp. 259-273.

[18] Dunn, M. G., Tarter, R. E., Mezzich, A. C., Vanyukov, M., Kirisci, L., \& Kirillova, G. (2002). Origins and consequences of child neglect in substance abuse families. Clinical Psychology Review, vol. 22, pp. 1063-1090.

[19] Duva, J \& Metzger, S. (2010). Addressing poverty as a major risk factor in child neglect: promising policy and practice. American Humane, vol. 25, pp. 63-74.

[20]Fang, X. \& Corso, F. S. (2007). Child maltreatment, youth violence, and intimate partner violence developmental relationships. American Journal of Preventive Medicine, vol. 33(4), pp. 281-290.

[21] Güler, N., Uzun, S., Boztaş, Z., \& Aydoğan, S. (2002). Anneleri tarafindan çocuklara uygulanan duygusal ve fiziksel istismar/ihmal davranışı ve bunu etkileyen faktörler. $C$. Ü. Tlp Fakültesi Dergisi, vol. 24 (3), pp. 128 - 134.

[22] Hannon, J. D., Tamis-Lemonda, C. S., \& Margolin, A. (2005). Father involvement in infancy: Influences of past and current relationships. Infancy, vol. 8(1), pp. 21-41

[23] Hindley, N., Ramchandani, P. G. \& Jones, D. P. H. (2006). Risk factors for recurrence of maltreatment: a systematic review. Arch Dis Child, vol. 91, pp. 744-752.

[24] Howe, D. (2005). Child abuse and neglect attachment, development and intervention. New York: Palgrave MacMillan.

[25] Kantarc1, M. N., Kandemir, E., Berber, G., Özcan, M. E., \& Şahin, E. (2013).Antiepileptic facilitated sexual assault: A case of incest. Klinik Psikofarmakoloji Bülteni, vol. 23(3), pp. 254-266. 
21-23 December, 2018 in Berlin - Germany

[26] Kaufman Kantor, G., Holt, M. K., Mebert, C. J., Straus, M. A., Drach, K. M., Ricci, L. R., Macallum, C. A., \& Brown, W. W. (2004). Development and preliminary psychometric properties of the Multidimensional Neglectful Behavior Scale-Child Report. Child Maltreatment, vol. 9(5), pp. 409-428.

[27] Kotch, J.B., Lewis, T., Hussey, J. M., English, D., Thompson, R., Litrownik, A. J., Runyan, D. K., Bangdiwala, S., Margolis, B., \& Dubowitz, H. (2008). Importance of early neglect for childhood aggression. Pediatrics, vol. 121(4), pp. 725-731.

[28] Kraut R., Patterson M., Lundmark V., Kiesler S., Mukopadhyay T. \& Scherlis, W. (2002). Internet paradox: a social technology that reduces social involvement and psychological well-being?. Journal of Social Issues, vol. 58(1), pp. 49-74.

[29] Laskey, A. L. (2011). Epidemiological issues in child maltreatment research, surveillance, and reporting. (Ed.). C. Jenny. In Child abuse and neglect (p. 1-9). Canada: Saunders.

[30] Lee, M. A., Schoppe-Sullivan, S. J., \& Dush, C. M. K. (2012). Parenting perfectionism and parental adjustment. Personality and Individual Differences, vol. 52, pp. 454-457

[31] Lewin, D., \& Herron, H. (2007). Signs, symptoms and risk factors: Health visitors' perspectives of child neglect. Child Abuse Review, vol. 16, pp. 93-107.

[32] Lewis, S. N., West, A. F., Stein, A., Malmberg, E., Bethell,K., Barnes, J., Sylva, K., \& Leach, P. (2008). A comparison of father-infant interaction between primary and non-primary care giving fathers. Child: Care, Health and Development, vol. 35(2), pp. 199-207.

[33] McBride, B.,Schoppe-Sullivan, S. J., \& Ho, M. (2005). The mediating role of fathers' school involvement on student achievement. Applied Developmental Psychology, vol. 26, pp. 201-216.

[34] McCoy M. L. \& Keen, S. M. (2014). Child abuse and neglect. New York: Psychology Press.

[35] Nadeau, M., \& Nolin, P. (2013).Attentional and executive functions inneglected children. Journal of Child \& Adolescent Trauma, vol. 6, pp. 1-10. 
International Conference on

\section{SOCIAL SCIENCE, HUMANITIES \& EDUCATION}

21-23 December, 2018 in Berlin - Germany

[36] Nicklas, E., \& Mackenzie, M. J. (2013). Intimate partner violence and risk for child neglect during early childhood in a community sample of fragile families. J Fam Viol, vol. 28, pp. 17-29.

[37] Nikulina, V., Widom, C. S. \& Czaja, S. (2011). Role of childhood neglect and childhood poverty in predicting mental health, academic achievement and crime in adulthood. American Journal of Community Psychology, vol. 48(3), pp. 309-321.

[38] Norman, R. E.,Byambaa, M., Butchart,A., Scott, J., \& Vos, T. (2012). The long-term health consequences of child physical abuse, emotional abuse, and neglect: A systematic review and meta-analysis. PLOS Medicine, vol. 9(11), pp. 1-31.

[39] Örsel, S., Karadağ, H., Karaoğlan Kahiloğulları, A., \& Aktaş, A. (2011). Psikiyatri hastalarında çocukluk çağı travmalarının sıklığı ve psikopatoloji ile ilişkisi. Anadolu Psikiyatri Dergisi, vol. 12, pp. 130-136.

[40] Özcan N. K., \& Buzlu S. (2005). Problemli internet kullanımını belirlemede yardımc1 bir araç: İnternette Bilişsel Durum Ölçeği”’nin üniversite öğrencilerinde geçerlik ve güvenirliği. Bağımlılık Dergisi, vol. 6(1), pp. 19-26.

[41] Özen, D. Ş. (2009). Ergenlerde anneden algılanan kabul/ilgi ile benlik-algısı arasındaki ilişki: babadan algılanan kabul/ilginin aracı rolü. Türk Psikoloji Yazllarl, vol. 12 (24), pp. 28-38.

[42] Özkardeş, O. G. (2011). Baba Olmak. Ana-Baba Okulu, Ed.: Haluk Yavuzer, İstanbul: Remzi Kitabevi, pp. 128-142.

[43] Pakiş, I., Yaycı, E., Günçe, E., Çelik, S., Uysal, C., \& Karapirli, M. (2008). Çocuk ihmaline bağlı ölüm olguları. Adli Tıp Bülteni, vol. 13(2), pp. 82-87.

[44] Palusci, V. J. (2011). Introduction. (Ed.). V. J. Palusci, H. Fischer. In Child abuse and neglect: a diagnost guide for physicians, surgeons, pathologists, dentists, nurses and social workers (p. 1-13). U.K.: Manson Publishing.

[45] Pancsofar, N., \& Vernon-Feagans L. (2002).Mother and father language input to young children: Contributions to later language development. Journal of Applied Developmental Psychology, vol. 27, pp. 571-587. 
[46] Perez-Fuentes, G., Olfson, M., Villegas, L., Morcillo, C., Wang, S., \& Blanco. C. (2013). Prevalence and correlates of child sexual abuse: a national study. Comprehensive Psychiatry, vol. 54, pp. 16-27.

[47] Polat, O. (2017). Tüm Boyutlarıyla Çocuk İstismarı: Tanımlar. Ankara: Seçkin Yayıncilik.

[48] Scannapieco M., \& Connell-Carrick K. (2005). Understanding child maltreatment: An ecological and developmental perspective. U.K.: Oxford University Press.

[49] Schumacher, J. A.; Slep, A. M. \& Heyman, R. E. (2001). Risk factors for child neglect. Aggression and Violent Behavior, vol. 6, pp. 231-254.

[50] Schmidt, C. J. (2011).Child maltreatment fatalities. (Ed.). V. J. Palusci, H. Fischer. In Child abuse and neglect: a diagnost guide for physicians, surgeons, pathologists, dentists, nurses and social workers (p. 193-215). U.K.: Manson Publishing.

[51] Smitherman, L C. (2011). Failure to thrive. (Ed.). V. J. Palusci, H. Fischer. In Child abuse and neglect: a diagnost guide for physicians, surgeons, pathologists, dentists, nurses and social workers (p. 216-229). U.K.: Manson Publishing.

[52] Soylu, N., Alplaslan, A. H., Ayaz, M., Esenyel, S., \& Oruç, M. (2013). Psychiatric disorders and characteristics of abuse in sexually abused children and adolescents with and without intellectual disabilities. Research ${ }_{2} N$ Developmental Disabilities, vol. 34, pp. 4334-4342.

[53] Straus, M. A. (2004). Guide to the Multidimensional Neglectful Behavior Scales. Available: http://pubpages.unh.edu/ mas2/NS9\%20GUIDE.pdf.

[54] Stith, S. M., Liu, T., Davies, L. C., Boykin, E. L., Alder, M. C., Harris, J., Som, A., McPherson, M. \& Dees, J. E. (2009). Risk factors in child maltreatment: A metaanalytic review of the literature. Aggression and Violent Behavior, vol. 1(1), pp. 13-29.

[55] Stoltenborgh, M., Bakermans-Kranenburg, M. J., \& Ijzendoorn, M. H. (2013). The neglect of child neglect: A meta-analytic review of the prevalence of neglect. Soc Psychiatry Psychiatr Epidemiol, vol. 48, pp. 345-355.

[56] Stone, S. (2007). Child maltreatment, out-of-home placement and academic vulnerability: A fifteen-year review of evidence and future directions. Children and Youth Services Review, vol. 29, pp. 139-161. 
International Conference on SOCIAL SCIENCE, HUMANITIES \& EDUGATION

21-23 December, 2018 in Berlin - Germany

[57] UNICEF (2003). A legaue of child maltreatment, deaths in rich nations. Innocenti Report Card, vol. 5, pp. 2-17.

[58] Waldfogel, J., Craigie, T. \& Brooks-Gunn, J. (2010). Fragile families and child wellbeing. Future Child, vol. 20(2), pp. 87-112.

[59] Valkenburg, B. M., \& Peter, J. (2008). Adolescents' identity experiments on the Internet: Consequences for social competence and self-concept unity. Communication Research, vol. 35(2), pp. 208-231. 